\title{
Production, carbon and nitrogen in stover fractions of corn (Zea mays L.) in response to cultivar development
}

\author{
Produção, carbono e nitrogênio nas frações do resíduo do milho (Zea mays L.) \\ em resposta ao desenvolvimento do cultivar
}

\author{
Julierme Zimmer Barbosa', Carla Fernanda Ferreira', Nicolas Zendonadi dos Santos², \\ Antonio Carlos Vargas Motta ${ }^{1 *}$, Stephen Prior ${ }^{3}$, Juarez Gabardo ${ }^{4}$
}

\author{
${ }^{1}$ Universidade Federal do Paraná/UFPR, Departamento de Solos e Engenharia Agrícola, Curitiba, PR, Brasil \\ ${ }^{2}$ Monsanto do Brasil Ltda., Santa Cruz das Palmeiras, SP, Brasil \\ ${ }^{3}$ National Soil Dynamics Laboratory, United States Department of Agriculture, Auburn, AL, USA \\ ${ }^{4}$ Universidade Federal do Paraná/UFPR, Departamento de Genética, Curitiba, PR, Brasil \\ ${ }^{*}$ Corresponding author: mottaufpr@gmail.com \\ Received in May 14, 2016 and approved in July 29, 2016
}

\begin{abstract}
Changes in quantity and quality of corn crop stover can have a large impact on soil conservation and soil carbon (C) sequestration over large areas. The aim of this study was to evaluate changes in production, concentration and amount of $\mathrm{C}$ and nitrogen (N) in corn stover fractions due to cultivar development. Two field experiments were conducted in the city of Rolândia (Paraná State, Brazil) using ten cultivars representing five technological levels: single cross hybrids, double or triple hybrids, commercial varieties, and creole cultivars. Plant heights and stalk, leaf, cob, husk and tassel weights were determined at final harvest. Elemental $\mathrm{C}$ and $\mathrm{N}$ analyses were performed in triplicate for each stover fraction. In general, the creole cultivars had greater height, more dry matter ( $\left.\mathrm{kg} \mathrm{ha}^{-1}\right)$ and $\mathrm{C}$ content $\left(\mathrm{kg} \mathrm{ha}^{-1}\right)$ in husks, leaves, tassels and stalks, particularly when compared to single cross hybrids or others hybrids. There was a direct relationship between $\mathrm{C} / \mathrm{N}$ ratio and corn selection for husks in both years and for the others fractions in one study year. This was due to the combined effects of increasing $\mathrm{C}$ and decreasing $\mathrm{N}$ due to crop selection. Large differences were observed within the same technological levels for the evaluated properties, suggesting a wide variation in genetic background. The quantity and quality of stover fractions vary among cultivars and may affect their use for soil cover, animal feed, biomass energy and other applications.
\end{abstract}

Index terms: C/N ratio; genetic breeding; no-tillage system; integrated crop-livestock systems; renewable energy.

\begin{abstract}
RESUMO
A alteração na quantidade e qualidade dos resíduos culturais do milho podem impactar a conservação do solo e o sequestro de $\mathrm{C}$ no solo para extensas áreas. O objetivo do estudo foi avaliar as alterações na produção, concentração e quantidade de C e N nas frações do resíduo do milho em resposta ao desenvolvimento do cultivar. Foram conduzidos dois experimentos de campo na cidade de Rolândia (estado do Paraná, Brasil), sendo cultivados dez cultivares representantes dos cinco níveis tecnológicos que seguem: híbridos de cruzamento simples, duplo ou triplo, variedades comerciais e cultivares crioulas. No final do ciclo foi determinada a altura das plantas e o peso de colmos, folhas, sabugos, brácteas e pendão. Foi realizada a análise elementar em triplicata para C e N em cada fração do resíduo. Em geral, cultivares crioulas tiveram maior altura de planta e matéria seca ( $\left.\mathrm{kg} \mathrm{ha}^{-1}\right)$ e conteúdo de $\mathrm{C}\left(\mathrm{kg} \mathrm{ha}^{-1}\right)$ nas brácteas, folhas, pendões e colmo, principalmente em comparação aos híbridos simples ou outros híbridos. Ocorreu relação direta entre a relação C/N e a seleção do milho para brácteas para ambos os experimentos e para outras frações no primeiro experimento. Esse resultado foi devido ao aumento do $\mathrm{C}$ e redução do $\mathrm{N}$ pela seleção da cultura. Foi observada diferença dentro do mesmo nível tecnológico para as variáveis analisadas, sugerindo ampla variação de linhagem genotípica. A quantidade e a qualidade das frações do resíduo variaram entre cultivares de milho e pode afetar o seu uso como cobertura de solo, alimentação de animais, energia e outros.
\end{abstract}

Termos para indexação: Relação C/N; melhoramento genético; plantio direto; sistemas integrados de lavoura-pecuária; energias renováveis.

\section{INTRODUCTION}

The increase in corn grain production throughout its domestication occurred because of the interaction between genetic improvement and cultural practices (Lee; Tollenaar, 2007). Aiming at higher grain production, plant breeding culminated in selecting corn plants with different physiological and phenotypic characteristics, such as more erect leaves, smaller plants, shorter time for grain filling and more nutrients exported with grain (Duvick et al., 2004; Santos et al., 2012; Ferreira et al., 2012). In recent years, hybrids generally have represented most of the corn 
cultivars available to farmers (Cruz; Pereira, 2008), while commercial varieties and creole comprised a small fraction of the area planted with corn in Brazil.

In general, soil organic matter (SOM) is known to be very important for maintaining soil quality and therefore long-term agricultural productivity. The amount of SOM depends on the balance between the addition and loss of $\mathrm{C}$, which can be influenced by climate, crop stover decomposition, soil management, and microorganism activity (Blanco-Canqui, 2013). The adoption of cropping systems with no soil tillage has been effective in increasing SOM levels due to a reduction in the loss of $\mathrm{C}$ by not turning over the soil (Kumar et al., 2012; Corbeels et al., 2016). In this sense, the intensification of crop rotations using crops with high stover addition (e.g., corn) contributes to positive soil C balance (Govaerts et al., 2009; Lugato; Jones, 2015).

No-tillage covered $50 \%$ of Brazilian area planted with annual crops in 2012 (Freitas; Landers, 2014). Alvarenga et al. (2001) estimated that at least $6000 \mathrm{~kg} \mathrm{ha}^{-1}$ year $^{-1}$ of residue is necessary to cover the soil surface for good soil protection. Corn stover with a high $\mathrm{C} / \mathrm{N}$ ratio will decompose slower than species with a low $\mathrm{C} / \mathrm{N}$ ratio, which helps to prolong soil surface coverage and slows $\mathrm{N}$ mineralization of stover (Prior et al., 2006; Yanni et al., 2011). However, the impact of the variation in $\mathrm{C} / \mathrm{N}$ among the thousands of cultivars currently used by farmers is less understood.

Driven by economic and environmental factors, farmers have been pressured to use crop stover for livestock grazing in integrated crop-livestock systems (Sulc; Tracy, 2007) and as an alternative source of income for the production of fuels, energy and chemicals (Muth et al., 2013; Williams et al., 2016). Corn stover presents potential use for different purposes, considering corn's high stover production level and for being the most produced cereal in the world, especially in the major producing countries of the United States, China, and Brazil (USDA, 2016). However, excessive removal of stover can affect SOM; thus, soil management strategies are needed to overcome this impact (BlancoCanqui, 2013). In this sense, broad knowledge regarding differences in productive grain potential among corn cultivars contrasts with the limited knowledge concerning the quantity and quality of their stover, both of which are important for the adoption of soil management strategies and the selection of cultivars for different stover uses. The aim of this study was to evaluate changes in production, concentration and amount of $\mathrm{C}$ and nitrogen $(\mathrm{N})$ in corn stover fractions due to cultivar development.

\section{MATERIALS AND METHODS}

Field experiments were conducted during the 2005/2006 (Experiment 1) and 2006/2007 (Experiment 2) growing seasons in the Rolândia municipality $\left(23^{\circ} 16^{\prime}\right.$ South latitude, $51^{\circ} 28^{\prime}$ 'West longitude; $645 \mathrm{~m}$ elevation), Paraná state, Brazil. The local climate classifies as Cfa (Humid subtropical; Oceanic climate, without dry season; hot summer) according to the Köppen classification (Alvares et al., 2013) and the soil was classified as a Eutric Rhodic Ferralsol (IUSS Working Group, 2015). Before planting, soil samples $(0.0-10 \mathrm{~cm})$ were collected for chemical and granulometric analysis. The samples were air dried, ground, homogenized, passed through a $2 \mathrm{~mm}$ sieve, and analyzed for granulometric distribution, $\mathrm{pH}, \mathrm{Ca}$, $\mathrm{Mg}, \mathrm{Al}, \mathrm{K}, \mathrm{P}, \mathrm{Mn}, \mathrm{Fe}, \mathrm{Cu}, \mathrm{Zn}$, and organic matter (Table 1).

Ten corn cultivars were selected: two single cross hybrids (AG9010 and DKB950), two double cross hybrids (AG2040 and DKB979), two triple cross hybrids (AG5020 and DKB566), two commercial varieties (BR106 and BRS4157), and two creole cultivars (Palotina and GI045 [Tupy Pyta Sopé]). Detailed information concerning these cultivars has been previously reported (Santos et al., 2012). The cultivars were sown in a randomized complete block design with five replications using six-row plots $10 \mathrm{~m}$ in length. Row width was $0.80 \mathrm{~m}$, plant spacing within rows was $0.20 \mathrm{~m}$, and the established plant population was 62500 plants ha ${ }^{-1}$. Fertilizer providing $28 \mathrm{~kg} \mathrm{~N} \mathrm{ha}^{-1}, 70 \mathrm{~kg} \mathrm{P}_{2} \mathrm{O}_{5}$ $\mathrm{ha}^{-1}$ and $70 \mathrm{~kg} \mathrm{~K}_{2} \mathrm{O}$ ha $^{-1}$ was applied prior of sowing. Plots were hand-planted at two seeds per hole and thinned to the desired plant population at the $\mathrm{V}_{2}$ stage. To minimize $\mathrm{N}$

Table 1: Granulometric and soil chemical properties before field planting at Rolândia.

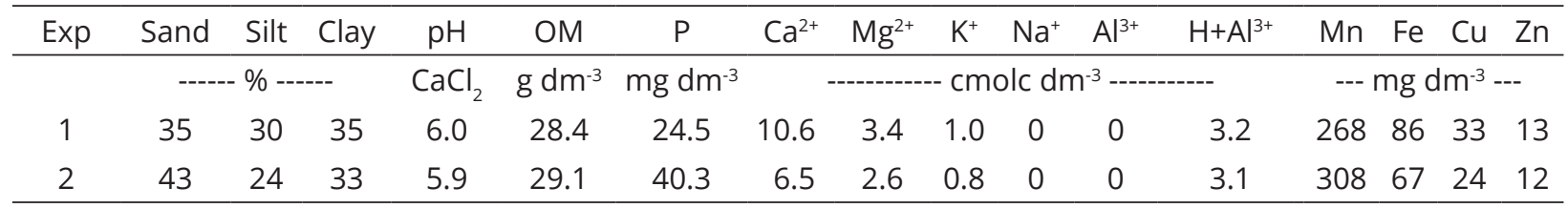

Sand, silt and clay (hydrometer method); $\mathrm{pH}\left(\mathrm{CaCl}_{2} 0.01 \mathrm{~mol} \mathrm{~L}^{-1}\right)$; organic matter $(\mathrm{OM})$ (volumetric method by potassium

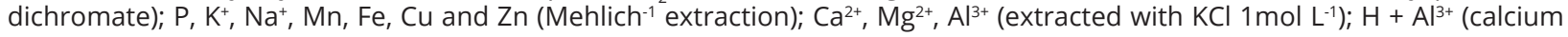
acetate $0.5 \mathrm{~mol} \mathrm{~L}^{-1}$ extraction). 
restrictions, urea was supplied at $135 \mathrm{~kg} \mathrm{~N} \mathrm{ha}^{-1}$ at the fourleaf stage $\left(\mathrm{V}_{4}\right)$. Plots were kept free of weeds, insects, and diseases following recommended practices for the region.

An on-site weather station recorded daily air temperature and rainfall throughout each season. During Experiment 1 (2005/2006 season), total rainfall in December, January, and February was 80, 56, and 367 mm, respectively. In Experiment 2 (2006/2007 season), the respective totals for these months were 226, 398, and $172 \mathrm{~mm}$. Meteorological conditions differed between the two experiments. Historical averages of total rainfall in December, January, and February are between 200-225 $\mathrm{mm}, 200-225 \mathrm{~mm}$, and 150-175 mm, respectively. Drought in the months of December and January in Experiment 1 coincided with the corn tasseling stage, which drastically reduced grain production (Santos et al., 2012).

At final harvest, fifteen whole plants were sampled from the second and fifth rows of each plot. Plants were separated into the following stover fractions: stalks, leaves, cobs, husks, and tassels. Stover fractions were oven dried $\left(75^{\circ} \mathrm{C}\right)$ to constant weight prior to mass determinations. The samples were then ground with a Wiley mill and passed through a $1 \mathrm{~mm}$ sieve. Subsamples were analyzed in triplicate to determine $\mathrm{C}$ and $\mathrm{N}$ concentrations via the dry combustion method using a CN-2000 LECO instrument (LECO Corporation, St. Joseph, MI). The C/N ratio was obtained using $\mathrm{C}$ and $\mathrm{N}$ concentrations, and these concentrations along with dry matter quantities were used to calculate $\mathrm{C}$ and $\mathrm{N}$ content $\left(\mathrm{kg} \mathrm{ha}^{-1}\right)$ in the stover fractions.

As previously stated, each experiment was conducted in a randomized complete block design with five replications. Obtained data were subjected to analysis of variance (ANOVA), and averages were compared by using the Tukey's test at a 5\% significance level $(\mathrm{p}<0.05)$ to characterize differences among treatments.

\section{RESULTS AND DISCUSSION}

Differences in production among stover cultivars with different technological levels were observed (Table 2). In Experiment 1, the single cross hybrids (AG9010 and DKB950) had lower height and leaf dry matter than other cultivars, while stalk, husk and tassel dry matter values were lower compared to commercial varieties (BRS4157 and BR106) and creole cultivars (GI045 and Palotina). In Experiment 2, the single cross hybrids showed lower height than commercial varieties and creole cultivars, lower weight for stalk dry matter than creole cultivars, lower leaf dry matter than double (DKB979 and AG2040) and triple cross hybrids (DKB566 and AG5020), and lower tassel dry matter than commercial varieties. However, cob dry matter weight was higher in commercial varieties (Experiment 1) and in the double cross hybrid (Experiment 2) compared to creole cultivars. Thus, the single cross hybrid plants were short and with high cob production, which is associated with a higher harvest index compared to commercial varieties and creole cultivars (Santos et al., 2012).

Corroborating our results, Lambert and Arnason (1982) found that a creole cultivar from Central America had higher dry matter accumulation in stalks, leaves and husks, while the hybrid used for comparison accumulated more dry matter in cobs. The opposite trend, between cob and husks in relation to plant selection, indicated less protection for corn grain by diminished thickness or number of husks. Evaluating more cultivars (14 creole cultivars and 15 hybrids), Tui et al. (2013) also observed this trend; however, some creole cultivars showed low stover production suggesting that variations were due to cultivar genealogy. The variation among corn cultivars within the same group reported by Tui et al. (2013) was observed in our study.

In general, plant selection may impact soil protection (both short and long term crop rotation) by changing the quantity of individual stover components. In the short term, higher amounts of stover from the creole and commercial cultivars should provide higher soil protection after harvesting. In the long term, the creole and commercial cultivars add more stalk and husk mass (which persist longer in the field compared to leaves) that improves soil protection for the next crop in the rotation. The husk probably has a higher specific surface area compared to stalks and may be a key component in protecting soil. However, given our good soil fertility and management conditions, the amount of stover added to the soil surface was above the $6000 \mathrm{~kg}$ ha $^{-1}$ year $^{-1}$ suggested by Alvarenga et al. (2001) as necessary to maintain soil protection.

Considering the decline in cob production due to drought in Experiment 1, one can infer that this reflects a higher allocation of dry matter to stalks and leaves in commercial varieties and creole cultivars and a greater allocation of dry matter to leaves in the double cross and triple cross hybrids (Table 2). That is, double cross hybrids and triple cross hybrids offset the effect of drought on cob production by increasing stalk and leaf production, which practically does not occur with the single cross hybrids. This increase is due to alterations in the source/sink photoassimilates, given that the reduction in the amount of sinks (grain) may favor photoassimilates storage in stalks and leaves (Lee; Tollenaar, 2007; White et al., 2012). In practical terms, this indicates that certain cultivars have greater secondary use potential (i.e., animal feed or energy 
production) in case of severe damage to the main use (grain production). However, in the experiment without drought (Experiment 2), double and triple cross hybrids showed potential for high production of both grain and stover, since it had higher stalk and leaf production than single cross hybrids but similar or greater cob production. In conclusion, plant selections differentially impacted stover fractions by decreasing stalks (major component of stover) and husks and increasing cob weight; however, there was great variation inside the same technological levels.

The $\mathrm{C}$ concentration for stover fractions presented in Table 3 indicated that cobs and stalks generally had the highest concentration, followed by leaves, tassels, and husks. There was large variation between crop years, with higher concentrations observed in the second year. In Experiment 1, the single cross hybrids had the highest $\mathrm{C}$ concentration in stalks and leaves, which were significantly different from the commercial varieties and creole cultivars. All hybrids (single, double and triple), except AG 9010, had higher cob C concentrations than the creole cultivars, while only husks varied between AG5020 and creole cultivars. In Experiment 2, the C concentration in stalks, leaves, husks, cobs, and tassels only showed variation among cultivars.

The increased stover production in Experiment 1 (Table 2) probably contributed to greater variation in $C$ concentration (Table 3). In this case, the cultivars with higher stalk dry matter (4,999 to 7,091 $\left.\mathrm{kg} \mathrm{ha}^{-1}\right)$ showed low C concentrations, while the opposite was observed for cultivars with lower stalk dry matter $\left(3,135\right.$ to $\left.3,680 \mathrm{~kg} \mathrm{ha}^{-1}\right)$. This suggests changes in

Table 2: Plant height and dry matter of stover fractions from ten corn cultivar in field experiments at Rolândia (Paraná State, Brazil).

\begin{tabular}{|c|c|c|c|c|c|c|c|}
\hline \multirow{2}{*}{ Cultivar $^{1}$} & & \multirow{2}{*}{ Height $(\mathrm{cm})$} & \multicolumn{5}{|c|}{ Dry matter $\left(\mathrm{kg} \mathrm{ha}^{-1}\right)$} \\
\hline & & & Stalks & Leaves & Cobs & Husks & Tassels \\
\hline & & \multicolumn{6}{|c|}{ Experiment 1} \\
\hline Single & AG 9010 & $212 c$ & $3,680 \mathrm{ef}$ & $2,305 c$ & 735abc & $1,025 \mathrm{de}$ & $62 d$ \\
\hline Single & DKB 950 & $221 b c$ & $3,135 f$ & $2,149 c$ & $770 a b c$ & $791 e$ & $62 d$ \\
\hline Double & AG 2040 & $261 a$ & 4,504 cde & $3,696 a b$ & $884 a b$ & $1,451 b c$ & $94 \mathrm{bcd}$ \\
\hline Double & DKB 979 & $252 a b$ & 3,818def & 3,332ab & $848 a b$ & 1,086 cde & $115 a b c$ \\
\hline Triple & DKB 566 & $250 a b$ & 4,745 cde & $3,216 b$ & $562 c$ & $900 \mathrm{e}$ & $71 \mathrm{~cd}$ \\
\hline Triple & AG 5020 & $254 a$ & $5,198 \mathrm{bc}$ & $3,871 a b$ & $670 b c$ & $1,379 \mathrm{bcd}$ & $92 \mathrm{bcd}$ \\
\hline Commercial & BRS 4157 & $258 a$ & $4,999 \mathrm{~cd}$ & $3,138 b$ & $903 a b$ & $1,364 \mathrm{bcd}$ & $132 a b$ \\
\hline Commercial & BR 106 & $264 a$ & $5,214 b c$ & $3,555 a b$ & $946 a$ & $1,958 a$ & $134 a b$ \\
\hline Creole & GI045 & $270 a$ & $6,358 a b$ & $3,673 a b$ & $562 c$ & $1,465 b$ & $142 a$ \\
\hline \multirow[t]{2}{*}{ Creole } & Palotina & $270 a$ & $7,091 a$ & 4,070a & $195 d$ & $1,996 a$ & $117 a b$ \\
\hline & & \multicolumn{6}{|c|}{ Experiment 2} \\
\hline Single & AG 9010 & $203 e$ & $2,904 b c$ & $2,164 d$ & $1,139 \mathrm{bcd}$ & $1,148 \mathrm{c}$ & $58 c$ \\
\hline Single & DKB 950 & 210de & $2,748 c$ & $2,253 \mathrm{~cd}$ & 1,387ab & $1,224 b c$ & $55 c$ \\
\hline Double & AG 2040 & $252 a b c d$ & $4,731 a$ & $3,218 a$ & $1,569 a$ & 1,627ab & $80 a b c$ \\
\hline Double & DKB 979 & 237cde & $3,864 a b c$ & $2,888 a b$ & 1,430ab & $1,490 b c$ & $108 a$ \\
\hline Triple & DKB 566 & $241 \mathrm{bcde}$ & $3,964 a b c$ & $2,830 a b c$ & $867 d$ & $1,397 b c$ & $71 \mathrm{bc}$ \\
\hline Triple & AG 5020 & $250 a b c d$ & $4,186 a b$ & $3,266 a$ & 1,403ab & $1,541 \mathrm{abc}$ & $79 a b c$ \\
\hline Commercial & BRS 4157 & $245 a b c d$ & $3,715 a b c$ & $2,422 \mathrm{bcd}$ & 1,311ab & $1,259 b c$ & $111 a$ \\
\hline Commercial & BR 106 & $265 a b c$ & $4,028 a b c$ & $2,591 \mathrm{bcd}$ & $1,228 b c$ & $1,954 a$ & $102 a b$ \\
\hline Creole & GI045 & $282 a b$ & $4,429 a$ & $2,327 \mathrm{bcd}$ & $874 d$ & $1,353 b c$ & $84 a b c$ \\
\hline Creole & Palotina & $286 a$ & $4,862 a$ & $2,792 a b c$ & $949 c d$ & 1,658ab & $81 a b c$ \\
\hline
\end{tabular}

${ }_{1}$ Single, double, triple, commercial and creole, respectively, single cross hybrids, double cross hybrids, triple cross hybrids, commercial varieties and creole cultivars. Averages followed by the same letter in the column do not differ among themselves by the Tukey test $(p<0.05)$. 
the amount of major plant constituents such as lignin, cellulose, and hemicellulose. Similar results were noted for leaves, although differences were smaller than in stalks probably due to large reserve storage capacity in stalks (White et al., 2012). Furthermore, the higher $\mathrm{C}$ concentration in stalks was expected since these cultivars seem to favor strengthening these structures to support the weight of ears; this was especially true for single cross hybrids that combine small size with high production (Duvick et al., 2004; Santos et al., 2012). For cobs, lower $\mathrm{C}$ concentrations in creole cultivars may reflect shifts in the proportion of major plant tissue components such as lignin, cellulose, hemicellulose, and protein. This could be one of the many factors influencing resistance to decomposition, biomass energy, and animal feed digestibility.

The amount of $\mathrm{C}$ stored in each stover fraction (Figure 1) varied widely among cultivars and fractions. The $\mathrm{C}$ content of stalks showed an inverse relationship for corn selection since the creole cultivars presented the highest values and single cross hybrids the lowest values. But the $\mathrm{C}$ content in the cob was higher for double hybrids compared to creole cultivars. For the content of $\mathrm{C}$ in the leaves, husks and tassels, creoles cultivars and single hybrids differed only in Experiment 1, and for Experiment 2 variations were only between cultivars. Regarding hybrids, the $\mathrm{C}$ content in leaves was higher in double cross and triple cross hybrids compared to single cross hybrids in Experiment 1. Husks and tassels followed the

Table 3: Carbon concentration in the stover fractions of ten corn cultivars in field experiments at Rolândia.

\begin{tabular}{|c|c|c|c|c|c|c|}
\hline \multirow{2}{*}{\multicolumn{2}{|c|}{ Cultivar $^{1}$}} & \multicolumn{5}{|c|}{ Carbon $\left(\mathrm{g} \mathrm{kg}^{-1}\right)$} \\
\hline & & Stalks & Leaves & Cobs & Husks & Tassels \\
\hline & & \multicolumn{5}{|c|}{ Experiment 1} \\
\hline Single & AG 9010 & $441 \mathrm{ab}$ & $433 a$ & $449 a b c$ & $425 a b$ & $436 a$ \\
\hline Single & DKB 950 & $442 \mathrm{a}$ & $433 a$ & $450 \mathrm{ab}$ & $426 a b$ & $432 \mathrm{a}$ \\
\hline Double & AG 2040 & $436 a b c$ & $428 a b$ & $452 \mathrm{a}$ & $423 a b c$ & $429 a$ \\
\hline Double & DKB 979 & 430 bcd & $428 a b$ & $451 a b$ & $424 a b$ & 429 a \\
\hline Triple & DKB 566 & $431 \mathrm{abcd}$ & $428 a b$ & $451 a b$ & $425 a b$ & 431 a \\
\hline Triple & AG 5020 & $435 a b c$ & $425 \mathrm{bc}$ & $453 a$ & $428 \mathrm{a}$ & $432 \mathrm{a}$ \\
\hline Commercial & BRS 4157 & $426 \mathrm{~cd}$ & $421 \mathrm{c}$ & $452 a$ & $424 a b$ & $430 \mathrm{a}$ \\
\hline Commercial & BR 106 & $426 \mathrm{~cd}$ & $427 \mathrm{~b}$ & $445 \mathrm{bc}$ & $425 a b$ & $437 a$ \\
\hline Creole & GI045 & $422 d$ & $427 \mathrm{~b}$ & $444 \mathrm{c}$ & $419 c$ & 438 a \\
\hline Creole & Palotina & \multicolumn{5}{|c|}{ Experiment 2} \\
\hline Single & AG 9010 & $452 \mathrm{a}$ & $438 a$ & $463 \mathrm{bc}$ & $441 \mathrm{ab}$ & $445 \mathrm{bc}$ \\
\hline Single & DKB 950 & $449 a b$ & $433 a b c$ & $463 \mathrm{bc}$ & $440 \mathrm{~b}$ & $446 \mathrm{~b}$ \\
\hline Double & AG 2040 & $444 a b$ & $426 \mathrm{~cd}$ & $464 \mathrm{bc}$ & $442 a b$ & $440 \mathrm{c}$ \\
\hline Double & DKB 979 & $439 \mathrm{~b}$ & 429 bc & $463 \mathrm{bc}$ & $444 a b$ & 443 bc \\
\hline Triple & DKB 566 & $444 a b$ & $428 \mathrm{~cd}$ & $461 \mathrm{bc}$ & $442 a b$ & $443 \mathrm{bc}$ \\
\hline Triple & AG 5020 & $443 a b$ & $424 d$ & $469 a$ & $444 a b$ & $445 \mathrm{bc}$ \\
\hline Commercial & BRS 4157 & $443 a b$ & $426 \mathrm{~cd}$ & $465 \mathrm{~b}$ & $442 a b$ & 443 bc \\
\hline Commercial & BR 106 & $446 a b$ & $431 a b c$ & 462 bc & $443 a b$ & 445 bc \\
\hline Creole & GI045 & $443 a b$ & $436 a b$ & $463 \mathrm{bc}$ & $444 a b$ & $452 \mathrm{a}$ \\
\hline Creole & Palotina & $446 a b$ & $432 a b c$ & $461 \mathrm{c}$ & $445 a$ & $447 a b$ \\
\hline
\end{tabular}

${ }_{1}$ Single, double, triple, commercial and creole, respectively, single cross hybrids, double cross hybrids, triple cross hybrids, commercial varieties and creole cultivars. Averages followed by the same letter in the column do not differ among themselves by the Tukey test $(p<0.05)$. 
same trend; however, cob fractions followed the opposite pattern due to grain production (Duvick et al, 2004; Santos et al., 2012). In addition, the amount of $C$ in corn stover indicated that stalks were the major $\mathrm{C}$ reservoir followed by leaves, husks, cobs, and tassels.

The lower $\mathrm{C}$ content in single cross hybrid stalks was associated with smaller plant size, while the low $\mathrm{C}$ content of single cross hybrid leaves arises from changes in leaf architecture and size arising from genetic selection (Barker et al., 2005; Lee; Tollenaar, 2007). In general, the investment in husks for grain protection of ears decreased with cultivar development. This helps explain the lowest observed amount in the husk fraction for single cross hybrids despite the increased $\mathrm{C}$ accumulation in cobs. Additionally, in both years the average husks and cobs represented 13.8 and 13.8\% for single hybrids and 14.4 and $6.5 \%$ (data not shown) for creole cultivars, respectively. The corresponding values for total C were 455 and $462 \mathrm{~kg} \mathrm{ha}^{-1}$ and 699 and $294 \mathrm{~kg} \mathrm{ha}^{-1}$. For tassels, single cross hybrids accumulate less $\mathrm{C}$, indicating a breakthrough regarding the efficiency in male flower production (Duvick et al., 2004). On the other hand, C content variations for double cross and triple cross hybrids (compared to single cross hybrids) were similar to those observed for dry matter production (Table 2); this suggest that double and triple cross hybrids have greater potential for different uses than single crosses. In general, the small trend of $\mathrm{C}$ increment by selection cannot offset stover diminishment (especially stalks), therefore, less $\mathrm{C}$ may be added to the soil surface as result of selection.

The $\mathrm{N}$ concentration for each stover fraction presented in Table 4 indicated that regardless of stover fraction, the creole cultivars had higher $\mathrm{N}$ concentrations compared to single cross hybrids in Experiment 1. Additionally, $\mathrm{N}$ concentration was higher in stalks of commercial varieties compared to single cross hybrids. However, in Experiment 2, single cross hybrids had higher $\mathrm{N}$ concentrations than creole cultivars in husks only.
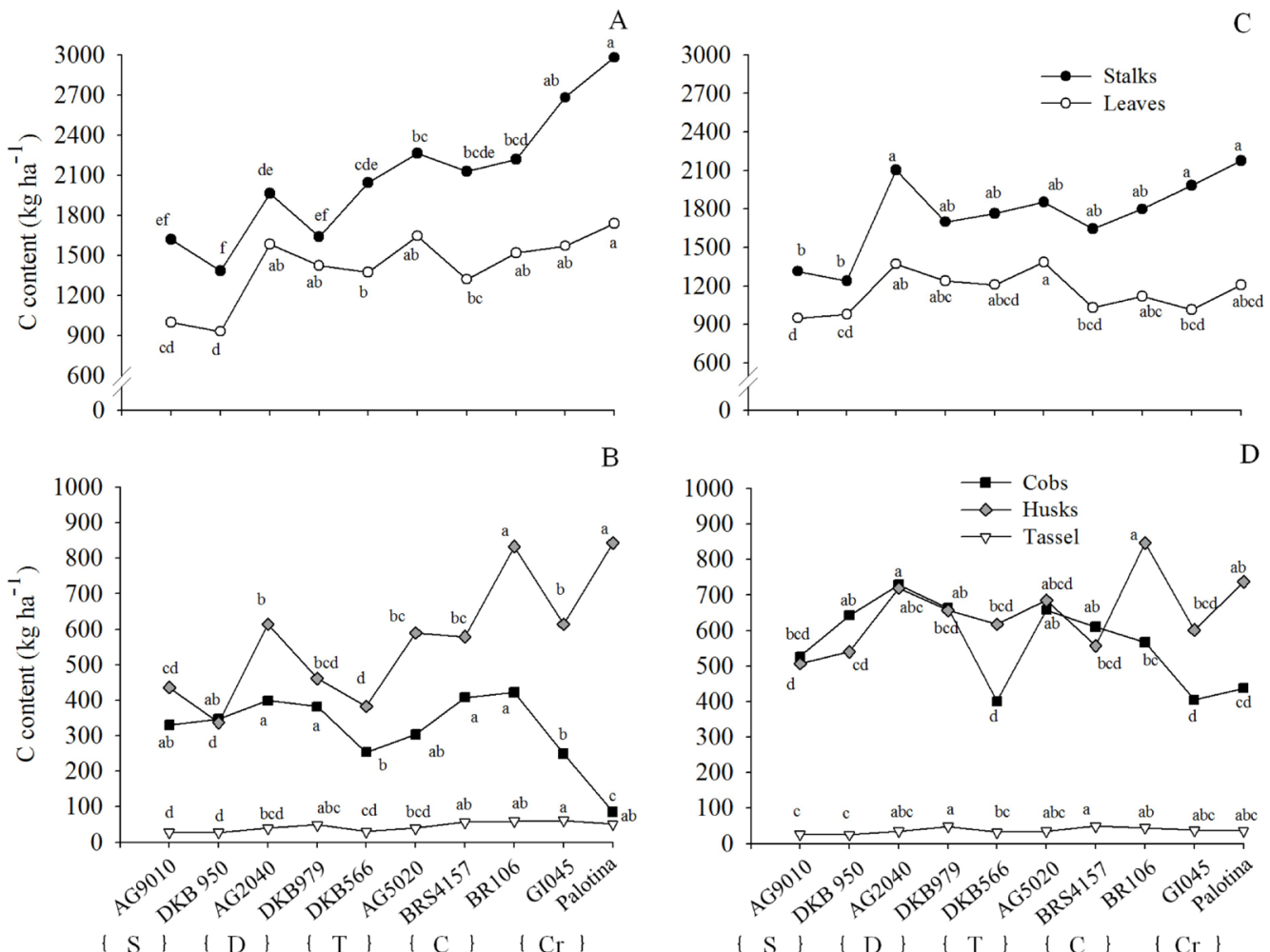

Figure 1: Carbon $(C)$ content in the stover fractions of ten corn cultivars in Experiment $1(A ; B)$ and Experiment 2 (C; D) at Rolândia. Averages followed by the same letter do not differ among themselves by the Tukey test $(p<$ 0.05). S, D, T, C and Cr, respectively, single cross hybrids, double cross hybrids, triple cross hybrids, commercial varieties and creole cultivars. 
Table 4: Nitrogen concentration in the stover fractions of ten corn cultivars in field experiments at Rolândia.

\begin{tabular}{|c|c|c|c|c|c|c|}
\hline \multirow{2}{*}{\multicolumn{2}{|c|}{ Cultivar $^{1}$}} & \multicolumn{5}{|c|}{ Nitrogen $\left(\mathrm{g} \mathrm{kg}^{-1}\right)$} \\
\hline & & Stalks & Leaves & Cobs & Husks & Tassels \\
\hline & & \multicolumn{5}{|c|}{ Experiment 1} \\
\hline Single & AG 9010 & $10.1 \mathrm{~d}$ & $9.7 \mathrm{~cd}$ & $5.4 \mathrm{c}$ & $5.1 \mathrm{bc}$ & $7.7 \mathrm{~d}$ \\
\hline Single & DKB 950 & $11.1 \mathrm{~cd}$ & $9.2 \mathrm{~d}$ & $5.4 \mathrm{c}$ & $4.9 \mathrm{c}$ & $7.9 \mathrm{~cd}$ \\
\hline Double & AG 2040 & $14.2 \mathrm{abc}$ & $11.0 \mathrm{abc}$ & $6.2 \mathrm{c}$ & $7.3 a b c$ & $10.1 \mathrm{bc}$ \\
\hline Double & DKB 979 & $12.2 \mathrm{bcd}$ & $10.8 \mathrm{abcd}$ & $6.0 c$ & $6.4 \mathrm{bc}$ & $9.7 \mathrm{bcd}$ \\
\hline Triple & DKB 566 & $11.2 \mathrm{bcd}$ & $10.3 \mathrm{bcd}$ & $6.0 \mathrm{c}$ & $6.6 \mathrm{abc}$ & $9.1 \mathrm{bcd}$ \\
\hline Triple & AG 5020 & $13.6 \mathrm{abcd}$ & $12.1 \mathrm{a}$ & $7.5 \mathrm{c}$ & $7.0 \mathrm{abc}$ & $10.5 \mathrm{~b}$ \\
\hline Commercial & BRS 4157 & $16.6 \mathrm{a}$ & $11.1 \mathrm{abc}$ & $6.7 c$ & $7.4 a b$ & $9.2 \mathrm{bcd}$ \\
\hline Commercial & BR 106 & $14.8 a b$ & $11.3 a b c$ & $7.8 \mathrm{~b}$ & $7.2 a b c$ & $9.8 \mathrm{bcd}$ \\
\hline Creole & GI045 & $16.0 \mathrm{a}$ & $12.0 \mathrm{ab}$ & $11.3 \mathrm{a}$ & $7.4 a b$ & $11.0 \mathrm{ab}$ \\
\hline Creole & Palotina & \multicolumn{5}{|c|}{ Experiment 2} \\
\hline Single & AG 9010 & $6.9 a b$ & $8.6 \mathrm{~b}$ & $5.3 a b$ & $1.8 \mathrm{c}$ & $10.7 \mathrm{c}$ \\
\hline Single & DKB 950 & $7.4 a b$ & $9.4 a b$ & $3.2 \mathrm{~b}$ & $2.0 \mathrm{bc}$ & $10.9 c$ \\
\hline Double & AG 2040 & $7.5 a b$ & $8.7 \mathrm{~b}$ & $3.6 \mathrm{ab}$ & $3.4 a b c$ & 11.9 bc \\
\hline Double & DKB 979 & $8.6 a b$ & $9.9 a b$ & $3.8 \mathrm{ab}$ & $3.2 a b c$ & 12.2 bc \\
\hline Triple & DKB 566 & $6.2 \mathrm{~b}$ & $9.7 a b$ & $5.8 \mathrm{a}$ & $3.2 a b c$ & $12.2 \mathrm{bc}$ \\
\hline Triple & AG 5020 & $6.6 a b$ & $10.4 a b$ & $3.2 \mathrm{~b}$ & $3.3 a b c$ & $12.0 \mathrm{bc}$ \\
\hline Commercial & BRS 4157 & $10.4 \mathrm{a}$ & $11.3 a b$ & $4.3 a b$ & $3.1 a b c$ & $11.4 \mathrm{c}$ \\
\hline Commercial & BR 106 & $8.2 a b$ & $9.1 \mathrm{ab}$ & $4.0 \mathrm{ab}$ & $3.7 \mathrm{ab}$ & $13.1 \mathrm{ab}$ \\
\hline Creole & GI045 & $10.5 a$ & $9.8 a b$ & $5.3 a b$ & $4.1 \mathrm{a}$ & $14.3 a$ \\
\hline Creole & Palotina & $10.4 \mathrm{a}$ & $12.1 \mathrm{a}$ & $5.1 \mathrm{ab}$ & $4.4 \mathrm{a}$ & $12.3 \mathrm{bc}$ \\
\hline
\end{tabular}

${ }_{1}^{1}$ Single, double, triple, commercial and creole, respectively, single cross hybrids, double cross hybrids, triple cross hybrids, commercial varieties and creole cultivars. Averages followed by the same letter in the column do not differ among themselves by the Tukey test $(p<0.05)$.

As Arnon (1975) indicated, about $60 \%$ of the $\mathrm{N}$ found in corn kernels was provided by other plant parts by redistribution, while the remaining $40 \%$ was obtained from sources external to the plant. Accordingly, there can be reduction in tissue $\mathrm{N}$ concentrations which are nutrient sources for grain. In Experiment 1 (dry growing season), corn stover fractions showed higher $\mathrm{N}$ concentrations than Experiment 2 (normal growing season). Under unfavorable environmental conditions, there normally is lower $\mathrm{N}$ export via grains (Santos et al., 2012; Ferreira et al., 2012) allowing for greater accumulation in stover and increased $\mathrm{N}$ concentration. The possible greater redistribution of $\mathrm{N}$ to grain should have favored the occurrence of lower $\mathrm{N}$ concentrations in stover of cultivars with increased harvest index. In addition, Pommel et al. (2006) reported that hybrids with early leaf senescence had reduced leaf $\mathrm{N}$ concentrations due to redistribution of $\mathrm{N}$ to ears than hybrids with delayed leaf senescence. Factors related to $\mathrm{N}$ redistribution to ears helps explain $\mathrm{N}$ variations (Table 4) in single cross hybrids (early maturing, high harvest index) and creole cultivars (cycle late, low harvest index), while other hybrids were intermediate (Table 4). Likewise, Tui et al. (2013) noted lower $\mathrm{N}$ concentrations in the majority of hybrids, although some hybrids displayed values similar to creole cultivars.

The amount of $\mathrm{N}$ present in each fraction (Figure 2) indicated that the Experiment 1 single cross hybrid stalks and leaves had lower $\mathrm{N}$ content than commercial varieties and creole cultivars evaluated. While in Experiment 2, only single cross hybrids and creole cultivars were different for stalk $\mathrm{N}$ content. In Experiment 1, single cross hybrids accumulated 
less $\mathrm{N}$ in husks than creole cultivars, while accumulation in cobs was variable among cultivars (Figure 2). Changes among cultivars were directly influenced by dry matter accumulation patterns (Table 2) and $\mathrm{N}$ concentrations of stover fractions (Table 4). In general, stalks and leaves were the main fractions in terms of $\mathrm{N}$ content (20 to 118 $\mathrm{kg} \mathrm{ha}^{-1}$ ), while the remaining stover fractions had lower $\mathrm{N}$ content (cobs: 3 to $7 \mathrm{~kg} \mathrm{ha}^{-1}$; husks: 2 to $17 \mathrm{~kg} \mathrm{ha}^{-1}$; tassel: 0.5 to $\left.1.6 \mathrm{~kg} \mathrm{ha}^{-1}\right)$. This same trend of $\mathrm{N}$ content in corn stover fractions was observed by Lambert and Arnason (1982). Furthermore, the authors found that stover N content was superior in the creole cultivar compared to the highly productive hybrids due to differences in stover yields and redistribution efficiencies of cultivars.

Based on the $\mathrm{C} / \mathrm{N}$ ratio, differences could be determined among cultivars for stover (Figure 3). In Experiment 1, the single cross hybrids had a higher $\mathrm{C} / \mathrm{N}$ ratio than creole cultivars for all fractions evaluated, while the double cross hybrids and triple cross hybrids had higher $\mathrm{C} / \mathrm{N}$ ratio in the cob fraction than creole cultivars. For
Experiment 2, the single cross hybrids had a higher $\mathrm{C} / \mathrm{N}$ ratio only in the husk, being superior to the other cultivars evaluated. Differences among cultivars were expected because of wide variations in $\mathrm{C}$ and $\mathrm{N}$ concentrations discussed above (Tables 3 and 4, respectively).

Plant $\mathrm{C} / \mathrm{N}$ ratio has been shown to be important for determining immobilization/mineralization and velocity of residue decay. Yanni et al. (2011) compared nine pairs of $\mathrm{Bt}$ (Bacillus thuringiensis) corn and non-Bt corn hybrids and found that $\mathrm{Bt}$ corn stalks may be more susceptible to decomposition than non-Bt corn stover; respective stalks $\mathrm{C} / \mathrm{N}$ ratios were 61 and 84. Prior et al. (2006) reported similar findings for soybean (Glycine $\max \mathrm{L}$.) where stover of modern cultivars had lower $\mathrm{C} / \mathrm{N}$ ratios (36 to 43 ) and higher $\mathrm{N}$ mineralization in comparison to a vintage soybean cultivar ( $\mathrm{C} / \mathrm{N}$ ratio of 51$)$. Thus, the wide variation in corn stover composition observed in our study suggests that $\mathrm{N}$ mineralization of stover fractions will likely vary with cultivar development. In practical terms, high $\mathrm{C} / \mathrm{N}$ ratio stover can cover the soil surface longer, but additional $\mathrm{N}$
A
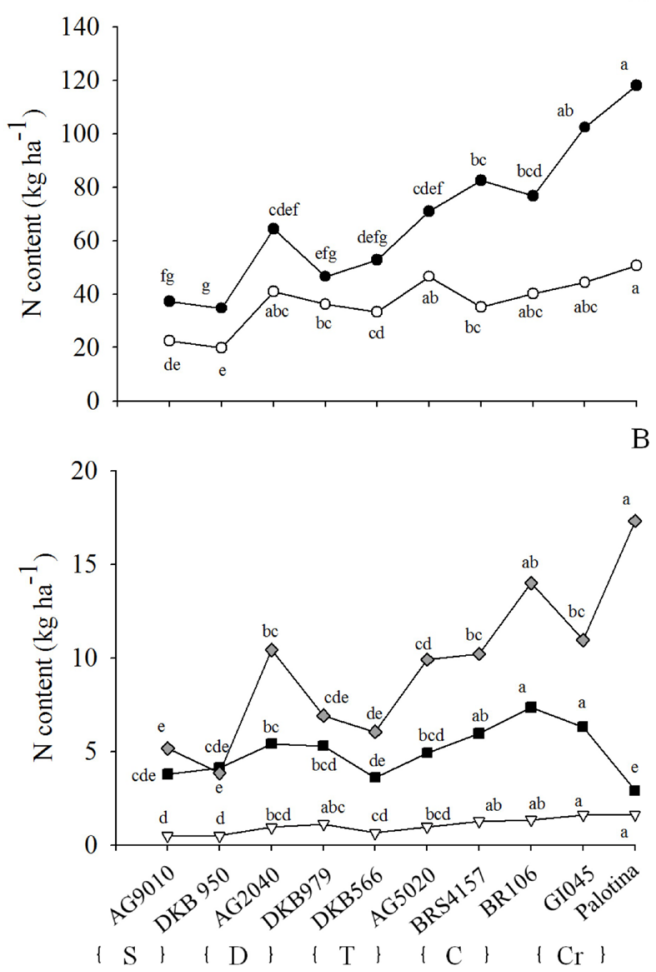
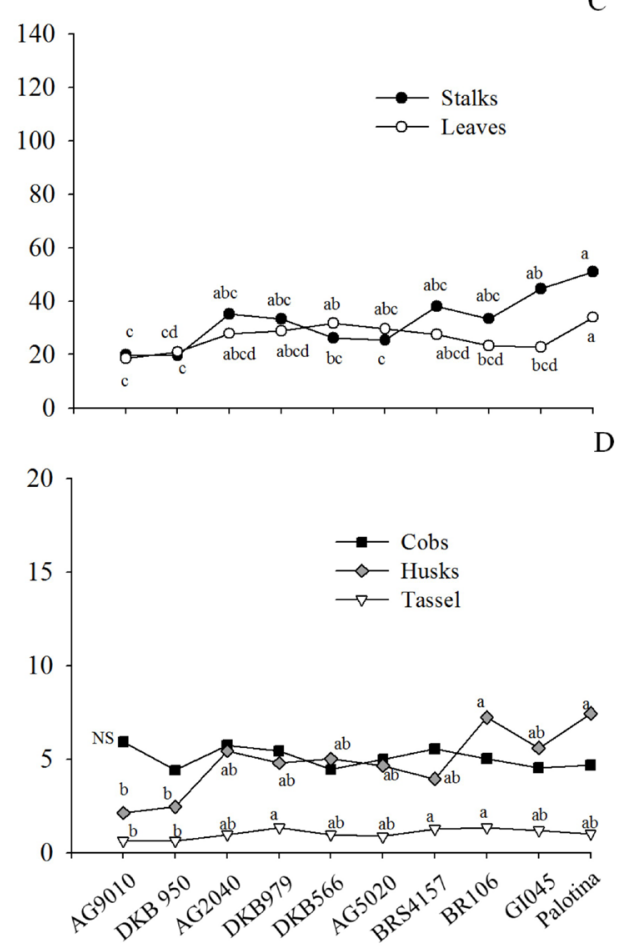

I S | | D | | T । I C । Cr ।

Figure 2: Nitrogen $(N)$ content in the stover fractions of ten corn cultivars in Experiment 1 ( $\mathrm{A} ; \mathrm{B})$ and Experiment 2 $(C ; D)$ at Rolândia. Averages followed by the same letter not differ among themselves by the Tukey test $(p<0.05)$. NS: not significant. S, D, T, C and Cr, respectively, single cross hybrids, double cross hybrids, triple cross hybrids, commercial varieties and creole cultivars. 
fertilization may be required to optimize crop growth. In the case of corn cultivar C/P, Ferreira et al. (2014) reported higher ratios (600 to 1200) in the stalks and leaves of single cross hybrids compared to creole cultivars. However, the high diversity of organic forms of $\mathrm{P}$ and significant quantities of inorganic forms both differed from predominant plant $\mathrm{N}$-compounds. Thus, predicting P release from stover using $\mathrm{C} / \mathrm{P}$ ratios is more difficult than analogous predictions of available $\mathrm{N}$ based on $\mathrm{C} / \mathrm{N}$ ratios (Noack et al., 2012).

When using corn stover for cattle feed, $\mathrm{C} / \mathrm{N}$ ratio does not necessarily affect stover quality but is a good indicator of nutritional value related to the amount of $\mathrm{N}$ and protein (Methu et al., 2001). Therefore, one can expect greater effect from the different $\mathrm{C} / \mathrm{N}$ ratios among corn stover fractions (leaves and stalks versus cobs and husks) in the first growing season $(\mathrm{C} / \mathrm{N}$ ratio $60 \%$ higher in single cross hybrids than other cultivars) (Figure 3 ).

When considering the influence of $\mathrm{C} / \mathrm{N}$ ratio on biorefinery systems in terms of stover fractions and their energy values, Pordesimo et al. (2005) found no significant difference in heat production (combustion) among corn stover fractions. Garlock et al. (2009) found increased production of glucose and xylose (prior to microbial fermentation into ethanol) in corn husks, followed by stalks, leaves, and cobs. Using leaves, stalks and husks+cobs, Seppälä et al. (2012) reported that gas production varied among fractions according to cultivar. Thus, $\mathrm{C} / \mathrm{N}$ ratio does not seem to interfere with energy efficiency of corn stover while variations in lignin, cellulose, hemicellulose and holocellulose concentrations are more important. Therefore, $\mathrm{C} / \mathrm{N}$ ratio is only indicative of poor $\mathrm{N}$ in cob and husk fractions (Table 4) which is interesting because they have less impact on soil nutrient export and thereby reduce replacement cost via fertilization (Thompson; Tyner, 2014).

The partial removal of the corn stover has been proposed for use in biorefinery systems (Muth et al., 2013; Williams et al., 2016). To preserve soil quality and system productivity, quantitative and qualitative attributes of stover along with other information (e.g. soil type, soil management system, climate) is required to carefully establish proper harvest
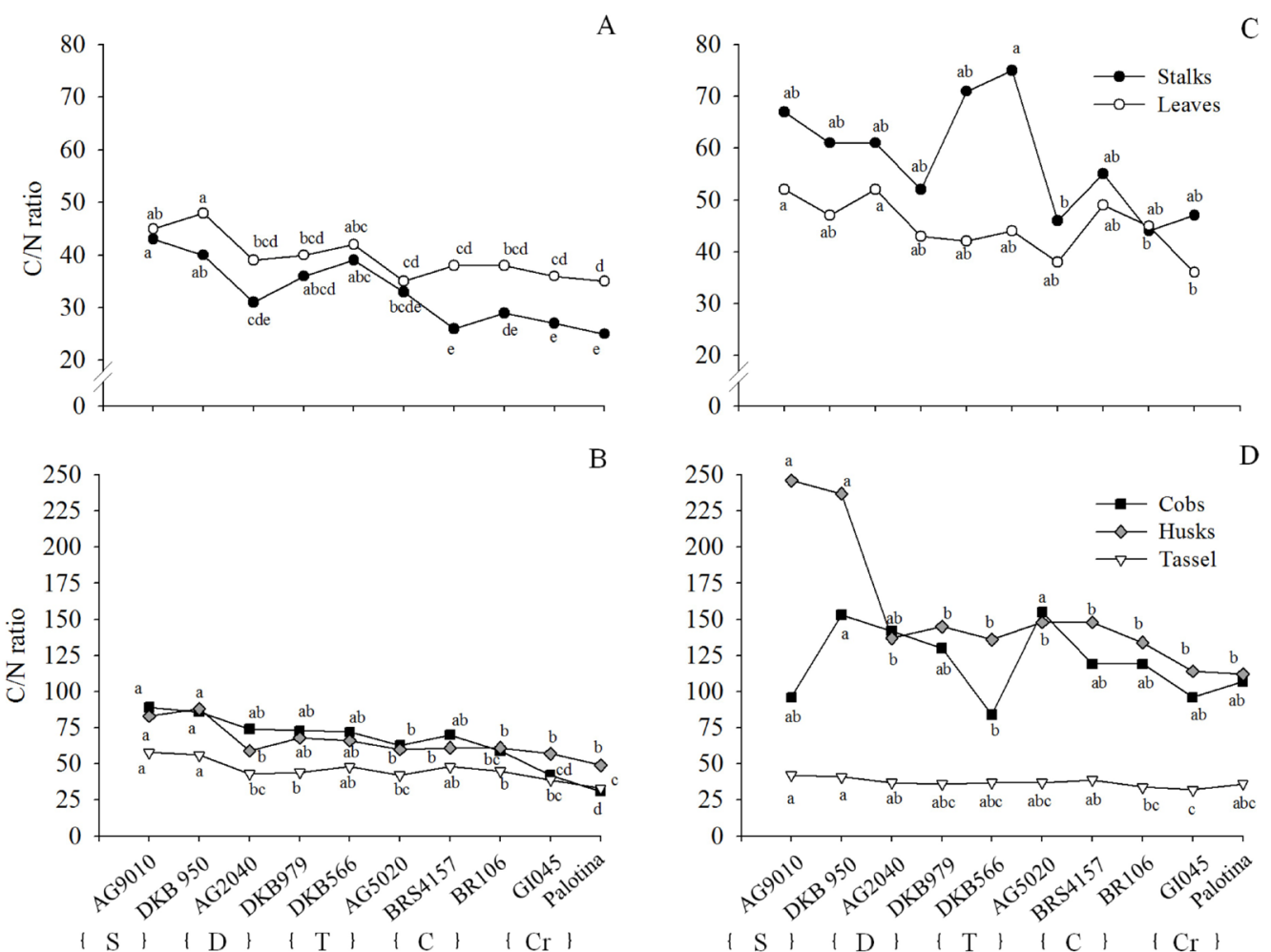

Figure 3: $\mathrm{C} / \mathrm{N}$ ratio of the stover fractions of ten corn cultivars in Experiment $1(\mathrm{~A} ; \mathrm{B})$ and Experiment $2(\mathrm{C} ; \mathrm{D})$ at Rolândia. Averages followed by the same letter not differ among themselves by the Tukey test $(p<0.05)$. $S, D, T$, $\mathrm{C}$ and $\mathrm{Cr}$, respectively, single cross hybrids, double cross hybrids, triple cross hybrids, commercial varieties and creole cultivars. 
levels (Blanco-Canqui, 2013; Lugato; Jones, 2015). It is worth noting that since hybrids are the cultivars most widely used in grain production systems (Cruz; Pereira, 2008), the removal and use of their stover is more likely. In our study, double cross and triple cross hybrids produced relatively more stalks and leaves than single cross hybrids (Table 2) thereby having a greater capacity of maintaining soil coverage in a scenario with partial stover removal. In general, single cross hybrids have relatively low $\mathrm{N}$ content in the stalks, leaves and husks than other hybrids (Figure 2), which decreases nutrient export potential. However, by harvesting only the cob fraction, $\mathrm{N}$ export would be similar among hybrids. Dual-purpose classification is well known in corn used for silage and grain production (Oliveira et al., 2013) and in wheat used for grazing and subsequent grain production (Assmann et al., 2014). Although more research is needed, our findings further indicate that some hybrids have greater dual-purpose potential (e.g., grain production, animal feed, and energy).

\section{CONCLUSIONS}

The quantity and quality of corn stover fractions were changed by cultivar development. In general, corn selection increased cob fractions but changed stover production by diminishing plant height and amount of stalks, husks, leaves, and tassels. Cobs and stalks had higher $\mathrm{C}$ concentration than leaves, husks, and tassels. However, climatic conditions largely impacted $\mathrm{C}$ concentration across years. Also, trends for increased $\mathrm{C}$ concentration in cobs and stalks from plant selection may impact tissue strength and increase lignin amounts. Based on $\mathrm{C}$ concentration and the amount of each stover fraction, stalks had the highest $\mathrm{C}$ content, followed by leaves, husks, cobs, and tassels. In contrast to $\mathrm{C}$, tassel $\mathrm{N}$ concentration decreased as a result of corn selection in both years. The other stover fractions showed a trend to decrease in one of two years. Our findings suggest that selection could enhance $\mathrm{N}$ efficiency. Additionally, drought impacted $\mathrm{N}$ accumulation in all stover fractions except tassels. By combining reductions in stover amounts and $\mathrm{N}$ concentrations, corn selection provided a large reduction in the amount of $\mathrm{N}$ found in stover fractions (except cobs). In this way, corn selection enhanced differences in $\mathrm{C} / \mathrm{N}$ ratio by increasing $\mathrm{C}$ and decreasing $\mathrm{N}$. On one hand, corn selection could decrease stover quantity leading to decreased soil coverage and protection after harvesting. On the other, increased $\mathrm{C} / \mathrm{N}$ ratio of some fractions from corn selection may result in slower stover decay and extend soil protection for the next crops. By changing quantity and quality of corn stover fractions, corn selection could impact soil protection, $\mathrm{C}$ and $\mathrm{N}$ cycling, animal feed quality, and biomass energy.

\section{REFERENCES}

ALVARENGA, R. C. et al. Plantas de cobertura de solo para sistema plantio direto. Informe Agropecuário. 22:25-36, 2001.

ALVARES, C. A. et al. Köppen's climate classification map for Brazil. Meteorologische Zeitschrift. 22(6):711-728, 2013.

ARNON, I. Mineral nutrition maize. International Potash Institute: Switzerland. 1975. 452 p.

ASSMANN, T. S. et al. Does cattle grazing of dual-purpose wheat accelerate the rate of stubble decomposition and nutrients released? Agriculture, Ecosystems \& Environment. 190:37-42, 2014.

BARKER, T. et al. Improving drought tolerance in maize. In: JANICK, J. (ed). Plant Breeding Reviews. John Wiley \& Sons, 2005. p. 173-253.

BLANCO-CANQUI, H. Crop residue removal for bioenergy reduces soil carbon pools: how can we offset carbon losses? BioEnergy Research. 6(1):358-371, 2013.

CORBEELS, M. et al. Evidence of limited carbon sequestration in soils under no-tillage systems in the Cerrado of Brazil. Scientific Reports. Available in: <http://www.nature.com/ articles/srep21450>. Access in: August, 03, 2016.

CRUZ, J. C.; PEREIRA FILHO, I. A. Cultivares de milho. In: CRUZ, J. C. (Ed.). Sistemas de produção de milho. Embrapa Milho e Sorgo. 2008. p. 159-170.

DUVICK, D. N. et al. Long-term selection in a commercial hybrid maize breeding program. In: JANICK, J. (ed). Plant Breeding Reviews. Part 2. Long term selection: crops, animals, and bacteria. John Wiley \& Sons. 2004. p. 109-151.

FERREIRA, C. F. et al. Influence of corn (Zea mays L.) cultivar development on grain nutrient concentration. International Journal of Agronomy. Available in: <http:// www.hindawi.com/journals/ija/2012/842582/>. Access in: August, 03, 2016.

FERREIRA, C. F. et al. Maize (Zea mays L.) cultivars nutrients concentration in leaves and stalks. Maydica. 59(1):65-71, 2014.

FREITAS, P. L.; LANDERS, J. N. The transformation of agriculture in Brazil through development and adoption of zero tillage conservation agriculture. International Soil and Water Conservation Research. 2(1):35-46, 2014.

GARLOCK, R. J. et al. Optimizing harvest of corn stover fractions based on overall sugar yields following fiber expansion pretreatment and enzymatic hydrolysis. Biotechnology for Biofuels. 2(1):29, 2009. 
GOVAERTS, B. Conservation agriculture and soil carbon sequestration: Between myth and farmer reality. Critical Reviews in Plant Sciences. 28(3):97-122, 2009.

IUSS Working Group WRB. World Reference Base for Soil Resources 2014, update 2015 International soil classification system for naming soils and creating legends for soil maps. World Soil Resources Reports No. 106. FAO: Rome, Italy, 2015. 192 p.

KUMAR, S. et al. Long-term no-till impacts on organic carbon and properties of two contrasting soil and corn yields in Ohio. Soil Science Society American Journal. 76(5):1798-1809, 2012.

LAMBERT, J. D. H.; ARNASON, L. T. Nitrogen distribution in hybrid and local corn varieties and its possible relationship to a declining soil nitrogen pool under shifting agriculture at Indian Churh, Belize. In: ROBERTSON, G. P.; HERRERA, R.; ROSSWALL, T. Nitrogen Cycling in Ecosystems of Latin America and the Caribbean. Springer, Netherlands. 1982. p. 119-127.

LEE, E. A.; TOLLENAAR, M. Physiological basis of successful breeding strategies for maize grain yield. Crop Science. 47(3):202-215, 2007.

LUGATO, E.; JONES, A. Modelling soil organic carbon changes under different maize cropping scenarios for cellulosic ethanol in Europe. BioEnergy Research. 8(2):537-545, 2015.

METHU, J. N. et al. Botanical and nutritional composition of maize stover, intakes and feed selection by dairy cattle. Livestock Production Science. 71(2-3):87-96, 2001.

MUTH, D. J. et al. Sustainable agricultural residue removal for bioenegy: A spatially comprehensive US national assessment. Applied Energy. 102:403-417, 2013.

NOAK, S. R. et al. Crop residue phosphorus: Speciation and potential bio-availability. Plant and Soil. 359(1-2):375-385, 2012.

OLIVEIRA, F. C. L. et al. Productive characteristics of maize hybrids at different cutting heights for silage and organic matter and mineral rates in post-harvest residues. Acta Scientarum. 35(2):133-138, 2013.
POMMEL, B. et al. Carbon and nitrogen allocation and grain filling in three maize hybrids differing in leaf senescence. European Journal of Agronomy. 24(3):203-211, 2006.

PORDESIMO, L. O. et al. Variation in corn stover composition and energy content with crop maturity. Biomass and Bioenergy. 28(4):366-374, 2005.

PRIOR, S. A. et al. Free-air carbon dioxide enrichment of soybean: Influence of crop variety on residue decomposition. Journal of Environmental Quality. 35(4):1470-1477, 2006.

SANTOS, N. Z. et al. Influence of corn (Zea mays L.) cultivar development on residue production. Journal of Plant Nutrition. 35(5):750-769, 2012.

SEPPÄLÄ, M. et al. Methane production from maize in Finland - Screening for different maize varieties and plant parts. Biomass and Bioenergy. 46:282-290, 2012.

SULC, R. M.; TRACY, B. F. Integrated crop-livestock systems in the U.S. Corn Belt. Agronomy Journal. 99(2):335-345, 2007.

THOMPSON, J. L.; TYNER, W.E. Corn stover for bioenergy production: Cost estimates and farmer supply response. Biomass and Bioenergy. 62:166-173, 2014.

TUI, S. H. K. et al. Assesing the potential of dual-purpose maize in southern Africa: A multi-level approach. Field Crops Research. 153:37-51, 2013.

UNITED STATES DEPARTMENT OFAGRICULTURE - USDA. Foreign Agricultural Service. World Agricultural Production. Circular Series. June 2016. 27p.

YANNI, S. F. et al. Field-grown Bt and non-Bt corn: Yield, chemical composition and decomposability. Agronomy Journal. 103(2):486-493, 2011.

WHITE, W. G. et al. The sugar, biomass, and biofuel potential of temperate by tropical maize hybrids. Global Change Biology Bioenergy. 4(5):496-508, 2012.

WILLIAMS, C. L. et al. Sources of biomass feedstock variability and the potential impact on biofuels production. BioEnergy Research. 9(1):1-14, 2016. 